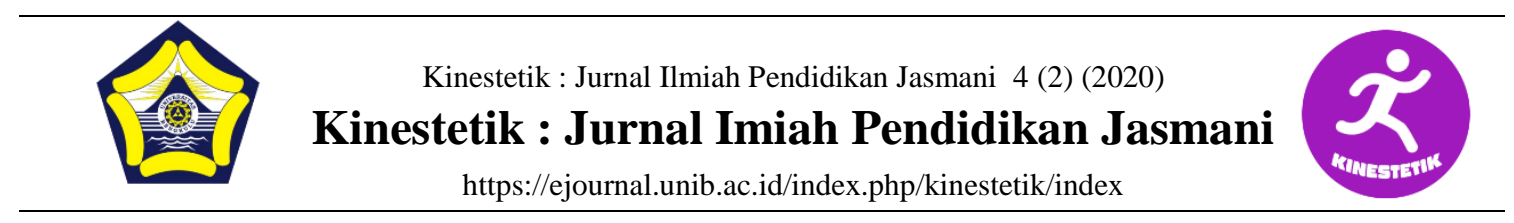

\title{
THE INFLUENCE OF PROJECT BASED LEARNING LEARNING OUTCOMES AND GENDER IN LEARNING SPORT PHYSICAL AND HEALTH (PJOK) IN SCHOOLS
}

\begin{tabular}{l} 
Eddy Marheni ${ }^{\mathbf{1}}$,Eko Purn \\
${ }^{12}$ Coaching, Sport Sciences F \\
${ }^{3}$ Sports Education, Doctoral \\
\hline Article Info \\
Article History: \\
Received September 2020 \\
Revised September 2020 \\
Accepted September 2020 \\
Available online September 2020 \\
\\
Keywords: \\
Learning Outcomes, PJOK, \\
Conventional; PBL \\
\hline
\end{tabular}

Eddy Marheni ${ }^{1}$,Eko Purnomo ${ }^{2}$, Nina Jermaina ${ }^{3}$

${ }^{12}$ Coaching, Sport Sciences Faculty, Universitas Negeri Padang, Padang, Indonesia

${ }^{3}$ Sports Education, Doctoral Education Students, Universitas Pendidikan Indonesia, Indonesia

\begin{abstract}
This study aims to determine the learning outcomes of PBL method with conventional methods and especially gender. This research was conducted at SMAN 12 Sijunjung. The research was carried out as much as $2 \times 45$ minutes according to the lesson hours. This type of research is Quasi Experiment Research or quasi-experimental. The main object in this study were male and female students in SMAN 12 Sijunjung. The results showed that with the application of problem-based learning (PBL) children would become more active, creative and innovative in learning PJOK, and create equal understanding and interest in PJOK subjects. To improve the quality of learning more effectively, the teacher must better understand the PJOK learning strategy.
\end{abstract}

${ }^{\square}$ Corresponding address: Padang, West Sumatra, Indonesia

* Corresponding email:ekopurnomo@fik.unp.ac.id
ISSN 2685-6514 (online)

ISSN 2477-331X (print)

DOI : $10.33369 /$ jk.v4i2.12412

\section{INTRODUCTION}

Physical education and sports programs in schools in many parts of the world need urgent and immediate reforms (Gorely et al., 2003), learning is an interaction that occurs between students and teachers, the form of interaction in question is reciprocal and programmed interaction and is related to teaching and learning activities or activities at school (Nasirudin, Setiawan, \& Yani. 2016). Learning is an activity that the doer is aware of. Before the 2013 curriculum, all learning activities forms were one-way, meaning that only teachers provided material and knowledge transfer. However, in the 2013 curriculum all forms and learning activities are carried out by placing students as the main actors and objects (student center learning) (Suherman, Ayi. 2014).

Physical education is one of education taught in schools. In physical education, many aspects are studied, not only cognitive and affective aspects but also psychomotor aspects. In addition, the norms in life that are also predicted by 2013 curriculum, or what is often called character education are also taught in physical education (such as social skills, 
fair play, sportsmanship, team work and many others) (Marheni, S, et al., 2019)(Nasirudin, Setiawan, \& Yani. 2016). It's undeniable that Sport Physical and Health Educatian (PJOK) subjects in schools are subjects that produce results for students, because with this PJOK subjects students can release fatigue or as a place to refresh their minds from subjects that require to think hard, like other subjects. But not all students have the same interest in PJOK, many factors influence this, a factor that's no less important is the factor of gender differences.

The social construction of the body has become very important to femininity and masculinity construction, and has shaped enduring meta themes through much research on physical education and gender. (Gorely et al., 2003). Deem \& Gilroy (1998) and Kay (1995) point to traditional family structures that disqualify physical activities such as sports as legitimate activities for women.

While the physical education experience of girls remains the academic focus and popular debate, the emerging attention for boys' education has highlighted the importance of sport as a reproductive site of hegemonic masculinity (Connell, 1983; Hickey et. Al., 1998). One result of the struggle over the past two decades has been the erosion of the traditional exclusivity of some activities for men, evidenced by increased visibility of female participants in activities such as football and cricket, marathon running and pole vaulting.(Gorely et al., 2003).

Koca, (2005) states that there are two things that cause hegemonic masculinity in sports, namely: First, sport is related to the male dimension, namely the physical skills seen, both sports also link men with the use of violence and violence. The majority of the world's population does not achieve the 60 minutes / day recommended moderate to vigorous physical activity (MVPA) level recommended by World Health Organization (World Health Organization, 2018). For example, when people see a boy who is crying, they will say, "How do boys cry, boys shouldn't cry." On the other hand, when they see a girl climbing a tree, people will say, "Girls aren't allowed to climb trees, it is rude. In addition, the authors mentioned detected a difference in MVPA between sex (106 minutes / day for boys and 64 minutes for girls) and body weight status (102 minutes for non-overweight vs 67 minutes for obese children) (Viciana et al., 2019). In addition, the form of support from the teacher and good communication will also make students better and motivated to learn physical education(Valley \& Graber, 2017). In addition, the motivation of the dam and each student also greatly determines the existing learning outcomes (Marheni, Purnomo, et al., 2019).

Researchers have formulated that the view of sport as a form of male or masculine activity has a major influence on the way men and women perceive sports, and also affects their interest in participating in sports. Supporters of other opinions also argue that gender differences in the world of sports are something related to body shape, type of sport and social factors which further encourage and determine views in society about whether an activity in sports is suitable for men or women (Supriyanto, Agus. 2008).

One way to change learning outcomes for the better is by changing learning methods. Problem-based learning has been proven by several researchers to be effective in improving student learning outcomes, especially in the application of the 2013 curriculum. 
Project Based Learning (PBL) is an active learning method and is carried out using a 2-way learning system. In addition, PBL learning also places students as a learning resource (compared to the teacher learning center). Then, in this PBL learning students are required to be able to use technology and also solve problems (Bell, S. 2010).

Problem based learning is a learning method that requires students to be able to identify, plan solutions, communicate solutions and solve problems and make decisions (Thomas, JW 2000). Problem based learning makes real life the main source in the implementation and practice of education, so that students are required to think critically and skillfully solve existing problems, so that students can apply the learning results obtained into real life later (Milla Minhatul Maula, Jekti Prihatin, Kamalia Fikri, 2014).

Finally, this study aims to see the learning outcomes of conventional methods with the problem-based learning (PBL) method in high school level schools. In addition, other impacts are also knowing the learning outcomes on the gender or gender of students.

\section{METHOD}

This research type is Quasi Experiment Research. Suryabrata (2006: 92) explains that the purpose of quasiexperimental research is to obtain information which is an estimate for information in circumstances that don't allow to control or manipulate all relevant variables. The population in this study were students of class XI Senior High School 12 Sijunjung, the sampling method used was random sampling technique and two classes were taken.
This research carried out the implementation of learning that took place as much as $2 \times 45$ minutes according to the lesson hours at Senior High School 12 Sijunjung. The class's further divided into experimental classes, namely class XI IPA 1 and control class XI IPA 2, the experimental class and control class both consist of 30 students whose total number of students is 60 people, the experimental class (XI IPA 1) uses (PBL) project based learning, while the control class uses (XI IPA 2) using conventional learning or socalled lecture method.

The dependent variable in this study is creativity ability, student motivation, affective, cognitive, and performance / practice in athletic learning. The control variables in this study were shot put, throwing javelins, and throwing discs according to the athletic material of the 2013 curriculum, while the independent variable in this study was problem based learning (PBL).

The research instruments used in this study consisted of: the syllabus and lesson plans, the learning implementation instrument used a self-assessment questionnaire to determine the extent to which students could take PBL learning, and the assessment instrument used a recapitulation of values in each class.

Table 1. Calculation of Results

\begin{tabular}{ll}
\hline Result & Information \\
\hline $91-100 \%$ & Very good \\
\hline $80-90 \%$ & Well \\
\hline $70-79 \%$ & Enough \\
\hline $60-69 \%$ & Less \\
\hline$<60 \%$ & Very less \\
\hline
\end{tabular}

\section{RESULTS AND DISCUSSION}

From the study results showed an increase in learning process for students. 
Table 1. Acquisition of comparison of learning outcomes

\begin{tabular}{clcc}
\hline No. & $\begin{array}{l}\text { Learning } \\
\text { model }\end{array}$ & $\begin{array}{c}\text { Value } \\
\text { Criteria }\end{array}$ & Total \\
\hline 1 & $\begin{array}{l}\text { Project } \\
\text { Based }\end{array}$ & $\mathrm{SB}$ & 3 \\
\cline { 3 - 4 } & $\begin{array}{l}\text { Learning } \\
\text { (PBL) }\end{array}$ & $\mathrm{B}$ & 25 \\
\cline { 3 - 4 } & $\mathrm{C}$ & 2 \\
\cline { 3 - 4 } & K & - \\
\hline 2 & Conventional & $\mathrm{KS}$ & - \\
\cline { 3 - 4 } & Learning & $\mathrm{SB}$ & 1 \\
\cline { 3 - 4 } & & $\mathrm{B}$ & 10 \\
\cline { 3 - 4 } & & $\mathrm{C}$ & 18 \\
\cline { 3 - 4 } & & $\mathrm{K}$ & 1 \\
\hline
\end{tabular}

The results of the learning carried out have a positive impact on students, including students being able to solve existing problems (Mahanal, 2008).

From the application of project based learning (PBL) results in Senior High School Sijunjung, researcher found that from this application, starting from planning / plaining students working together in the division of tasks, reporting strategies, finding resources, and creativity in making athletic sports support tools. which is needed in the learning process in accordance with the material that the researcher has shared.

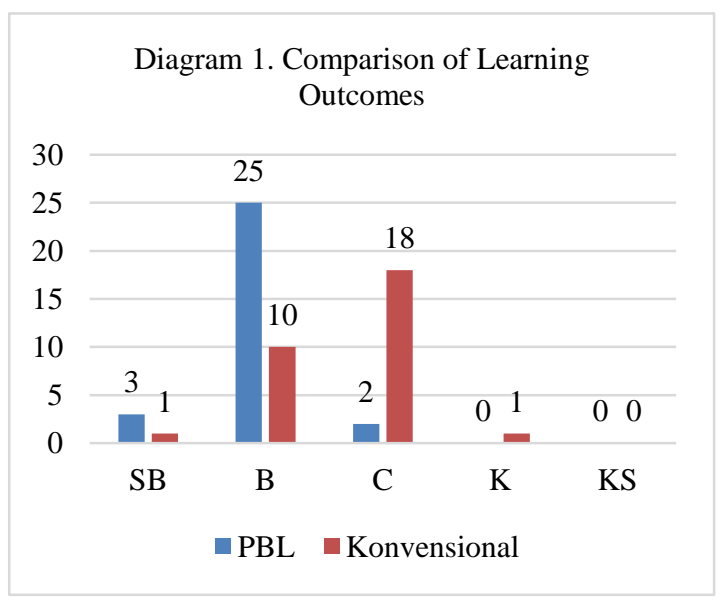

From the results of the average value in each class given through different learning models, there are the following results:

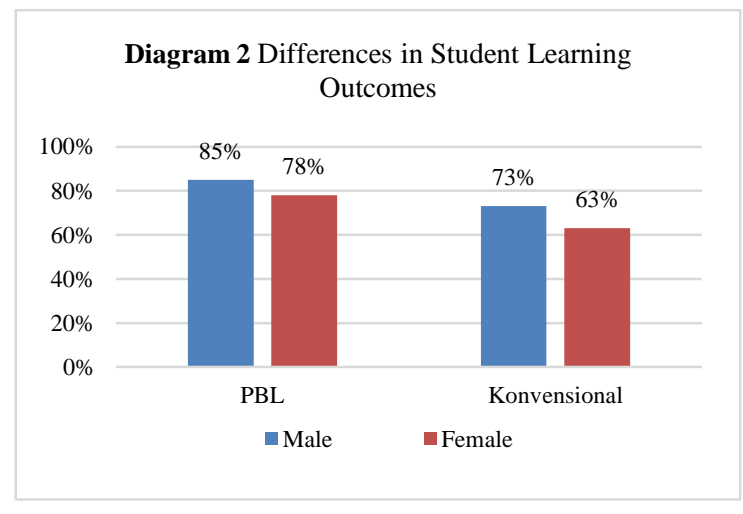

In accordance by the interviews and observations results in the field that students who were in Senior High School 12 Sijunjung when problem-based learning was applied to students, researcher found that by problem based learning a learning process would be created that was more effective than using the conventional learning process that is usually applied in the school. By applying this problem based learning, female students who have so far have less interest in sports, when the learning process takes place, female students just stay silent while waiting for their turn to try to do it, become more active in the learning process both in practice and in mastering the theory, the increase also occurred in male students.

As well as the creation of equality of understanding and interest of students in learning PJOK in schools which has been a problem with differences or different gender perspectives on PJOK in schools theory and practice in the sport.

\section{CONCLUSIONS}

This study shows that gender perspectives greatly influence the interests of male and female students in PJOK subjects in schools which involve male / masculine and feminine / female traits. 
Based on these results, there were differences in student learning outcomes between the experimental class XI IPA 1 using PBL and control class XI IPA 2 using conventional learning, the increase in learning outcomes was higher than conventional learning.

Problem based learning that's so appropriate to do in PJOK subjects at school because children can play an active role, participate directly in the field, and can be creative and better understand the content of the learning material and what is equally important is that the teacher can modify the learning style that has been used so far. The new learning style is problem-based learning (PBL) which is more effective in learning PJOK in schools which has an impact on student interest. During the implementation of the research, we faced several obstacles during the learning process, therefore the researcher gave several suggestions so that these obstacles can be overcome, among others;

\section{REFERENCES}

Gorely, T., Holroyd, R., \& Kirk, D. (2003). Muscularity, the Habitus and the Social Construction of Gender: Towards a gender-relevant physical education. British Journal of Sociology of Education, 24(4), 429-448. https://doi.org/10.1080/0142569030192 3

Marheni, E., Purnomo, E., \& Intan Cahyani, F. (2019). The Role of Motivation in Increasing Achievement: Perspective Sports Psychology. 7(Icssh 2018), 5962. https://doi.org/10.2991/icssh18.2019.14

Marheni, E., S, A., \& Purnomo, E. (2019). Application of Character Building with Physical Education (CBPE). Suluah Bendang: Jurnal Ilmiah Pengabdian Kepada Masyarakat, 20(1), 46. https://doi.org/10.24036/sb.0400

Valley, J. A., \& Graber, K. C. (2017). Genderbiased communication in physical education. Journal of Teaching in
Physical Education, 36(4), 498-509. https://doi.org/10.1123/jtpe.2016-0160

Viciana, J., Mayorga-Vega, D., \& ParraSaldías, M. (2019). Adolescents' physical activity levels on physical education and non-physical education days according to gender, age, and weight status. European Physical Education Review, 25(1), 143-155. https://doi.org/10.1177/1356336X1770 6683

World Health Organization. (2018). How much of physical activity is recommended?

https://www.who.int/news-room/factsheets/detail/physical-activity

Badar, I. T. (2014). Mendesain Model Pembelajaran Inovatif, Progresif, dan Kontekstual. Jakarta: Prenadamedia Group.

Bell, S. (2010). Project-based Learning for the 21st century: Skills for the future. The Clearing House, 83(2), 39-43.

Connell, R. W. (1983) Which Way Is Up? Essays on sex, class and culture (Sydney, Allen \& Unwin).

Deem, R. \& Gilroy, S. (1998) Physical activity, life-long learning and empowerment-situating sport in women's leisure, Sport, Education and Society, 3, pp. 89-104.

Hickey, C., Fitzclarence, L. \& Matthews, R. (Eds) (1998) Where the Boys Are: masculinity, sport and education (Geelong, Deakin University Press).

Kay, T. (1995) Women and Sport-a review of research (London, Sports Council).

Koca, C. 2005. Gender Role Orientation of Athletes and Nonathletes in a Patriarchal society. a Study in Turkey: Journal Reasearch. Volume 4.

Macdonald, Mandy dan Sprenger, Ellen. 1997. Gender dan Perubahan Organisasi. Yogyakarta: Insist Press

Mahanal, S. 2008. Pengembangan Perangkat pembelajaran deteksi Kualitas Sungai dengan Indikator Biologi Berbasis Konstruktivistik untuk Memberdayakan Berpikir Kritis dan Sikap Siswa SMA terhadap ekosistem Sungai di Malang. Unpublished dissertation. Malang: Magister Program Malang State University. 
Milla Minhatul Maula, Jekti Prihatin, Kamalia Fikri. 2014. Pengaruh Model PjBL (Project-Based Learning) terhadap Kemampuan Berpikir Kreatif dan Hasil Belajar Siswa pada Materi Pengelolaan Lingkungan. Bandung: Jember University (UNEJ). Unpublished article.

Mosse, Julia Cleves. 2007. Gender dan Pembangunan. Yogyakarta: Pustaka Pelajar

MZ, Zubaidah Amir. 2013. Perspektif Gender Dalam Pembelajaran Matematika. Bandung: Pendidikan Indonesia University Bandung. Marwah Vol. XII No.1

Nasirudin, Nanang, Setiawan, Ipang, \& Yani, Ahmad. 2016. Modul Program Guru Pembelajar PJOK SMP Kelompok Kompetensi Pedagogik - F. Jakarta: Direktorat Jenderal Guru Dan Tenaga Kependidikan Kementerian Pendidikan Dan Kebudayaan

Suherman, Ayi. 2014. Implementasi Kurikulum Baru Tahun 2013 Mata Pelajaran Pendidikan Jasmani (Studi Deskriptif Kualitatif pada SDN Cilengkrang). Sumedang: Mimbar Sekolah Dasar, Volume 1 Nomor 1 April 2014

Supriyanto, Agus. 2008. Pembentukan Karakter Olahragawan Ditinjau Dari Perbedaan Gender, Peran Serta Orangtua, Guru, Pelatih Olahraga Dan Keikutsertaan Dalam Aktivitas Olahraga Serta Jenis Olahraganya. Yogyakarta: Pendidikan Kepelatihan FIK UNY. Makalah ini disampaikan dalam rangka seminar olahraga Nasional ke II 8 November 2008 FIK UNY.

Suryabrata, S. 2006. Metodologi Penelitian. Jakarta: Gravindo Persada.

Tahar, Fahriah. 2012. Pengaruh Diskriminasi Gender Dan Pengalaman Terhadap Profesionalitas Auditor. Makassar: Fakultas Ekonomi Universitas Hasanuddin Makassar.

Thomas, J. W. (2000). A Review ff Research on Project-Based Learning. 